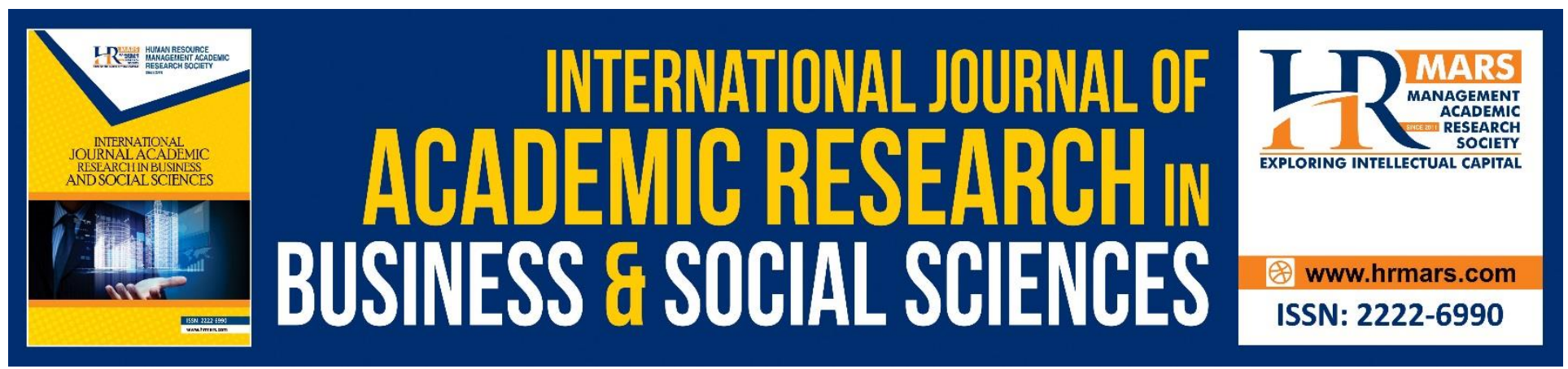

\title{
Enhancing Efficacy of Special Education Early Teachers: The External and Psychological Resilience Factors Perspectives
}

\author{
Amalina Ulya and Nor Aniza Ahmad
}

To Link this Article: http://dx.doi.org/10.6007/IJARBSS/v8-i7/4416

DOI: $\quad 10.6007 /$ IJARBSS/v8-i7/4416

Received: 20 May 2018, Revised: 11 June 2018, Accepted: 22 June 2018

Published Online: 08 July 2018

In-Text Citation: (Ulya \& Ahmad, 2018)

To Cite this Article: Ulya, A., \& Ahmad, N. A. (2018). Enhancing Efficacy of Special Education Early Teachers: The External and Psychological Resilience Factors Perspectives. International Journal of Academic Research in Business and Social Sciences, 8(7), 737-749.

\section{Copyright: (C) 2018 The Author(s)}

Published by Human Resource Management Academic Research Society (www.hrmars.com)

This article is published under the Creative Commons Attribution (CC BY 4.0) license. Anyone may reproduce, distribute, translate and create derivative works of this article (for both commercial and non-commercial purposes), subject to full attribution to the original publication and authors. The full terms of this license may be seen

at: http://creativecommons.org/licences/by/4.0/legalcode

Vol. 8, No. 7, July 2018, Pg. 737 - 749

http://hrmars.com/index.php/pages/detail/IJARBSS

JOURNAL HOMEPAGE

Full Terms \& Conditions of access and use can be found at http://hrmars.com/index.php/pages/detail/publication-ethics 


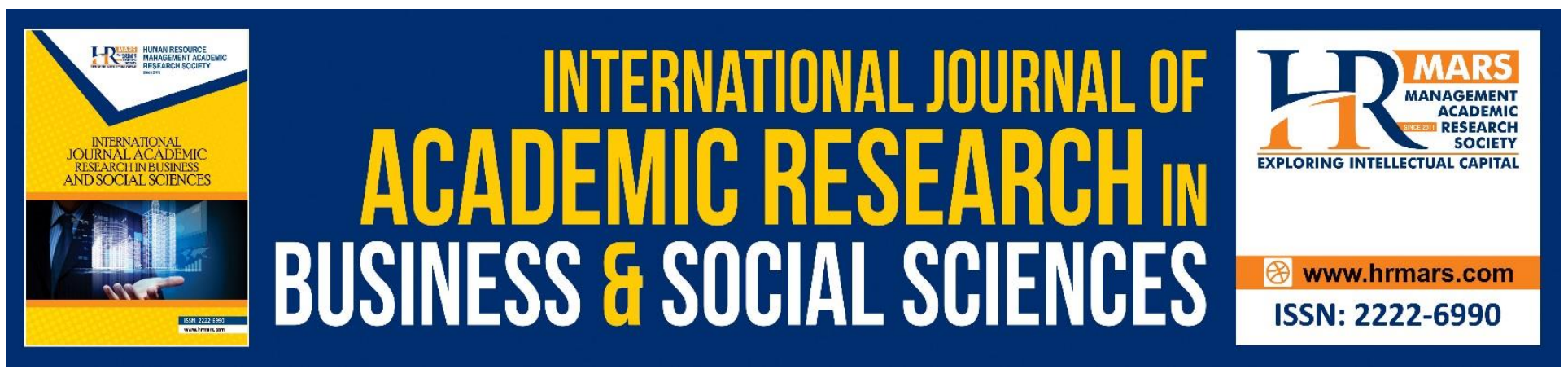

\title{
Enhancing Efficacy of Special Education Early Teachers: The External and Psychological Resilience Factors Perspectives
}

\author{
Amalina Ulya and Nor Aniza Ahmad \\ Faculty of Educational Studies, Universiti Putra Malaysia, 43400 UPM Serdang, Selangor, Malaysia
}

\section{Abstract}

The incremental value of efficacy enhancement of pre-teachers can also be predicted form the perspective of their resilience factors. The purpose of this study is to determine the relationship between resilience factors with personal and general teaching efficacy among special education preservice teachers. The resilience factor includes both external and psychological factors. The sample of this study consists of 194 special education pre-service teachers in Malaysian public universities. Descriptive analysis is carried out to determine the teaching efficacy level. The Pearson correlation is conducted to determine the relationship between resilience with teaching efficacy among preteachers of special education. Regression analysis is used to predict teaching efficacy based on resilience. The findings show high levels of confidence in personal teaching efficacy, while moderate low levels of confidence in general teaching efficacy. On overall basis, the resilience factors shows a high moderate level. The Pearson correlation generally shows that resilience factors have a positive and significant relationship with teaching efficacy. The regression analysis shows that resilience factor of conversion is an essential predictor for teaching efficacy. The implication of this study is for special education pre-service teachers to perceive both psychological and external resilience factors to enhance their teaching efficacy, professionally.

Keywords: Resilience, Teaching Efficacy, Special Education Pre-Service Teacher

\section{Introduction}

Teachers who are more efficacious dedicate more class time for educational accomplishments, offer response towards student learning and provide support to student that has problem in comprehending material, than teachers with lesser efficacy values (Hightower, Delgado, Lloyd, Wittenstein, Sellers \& Swanson, 2011). High efficacy teachers have more belief to influence students' learning; even the learning may perhaps more challenging (Tschannen-Moran \& Hoy, 2001). They are open to give more fresh ideas and are more prepared to try other teaching approaches to meet their students' needs well (Strong, Gargani \& Hacifazlioglu, 2011). Generally, teachers with high efficacy are more likely to involve in a productive and quality teaching performances (Dibapile, 2012). On the contrary, low efficacy teachers think that they only have least influence on student success, 
INTERNATIONAL JOURNAL OF ACADEMIC RESEARCH IN BUSINESS AND SOCIAL SCIENCES Vol. 8, No. 7, July 2018, E-ISSN: 2222-6990 @ 2018 HRMARS

which makes them easily surrender when encountered with a challenging condition. They are less resourceful, and regularly feel that students unable to learn because of the extenuating conditions (D’Elisa, 2015).

The teachers' self-efficacy beliefs are beliefs of the ability to encourage anticipated outcomes interrelated to teacher and students' performance, actions, and motivation in teaching and learning process (Gibbs \& Powell, 2012). Teachers' individual belief of his or her ability to affect student learning, is reflected as a crucial motivational principles that guide professional teachers' actions and student learning (Klassen, Tze, Betts, \& Gordon, 2007). A sufficiently significant clarification point out that teachers' level of self-efficacy is related to career fulfilment (Betoret, 2006), teachers' difficulties (Skaalvik \& Skaalvik, 2010) and also teachers' instructional performances, motivation, commitment as well as teaching performances in the lesson (Skaalvik \& Skaalvik, 2010; Somech \& Drach-Zahavy, 2000). Efficacy of the teacher also corresponds to students' outcomes for such as students' selfconfidences and engagement, motivation, and attainment (Bong, 2008; Eren, 2009). General teaching efficacy beliefs concept is linked to confidence on the task which is expected to be shifted when learners are subjected to vicarious learning experiences or social persuasion. Meanwhile, the actual teaching experiences through the teaching practices have a better impression on personal teaching efficacy (Ravikumar, 2013). General teaching efficacy has also revealed a decline in student in teaching (Wright, 2013), which proposes that the confidence of early teachers may be tarnished when they are encountered with the experiences and complexities of the teaching task.

Many researches seem to proclaim that challenges are higher in special education teachers than in general education teachers (Eichinger, 2000; Lazarus, 2006) and self-efficacy is an attribute of high quality special education teachers. The teachers who are confident, or efficacious have presented: a) the capability to produce and assess alternative sequences of action when early accomplishment is not met; b) improved performance by raising levels of effort and determination; and c) better capability to deal with a difficult condition by influencing cognitive and responsive processes related to the condition (Martin, 2006). Therefore, a trainee who will be a future teacher with a stronger sense of self-efficacy believes of the capability to positively influence the learning of the students.

A profession related to the special education is currently becoming a challenging profession. This is because the teachers need to educate students who had diverse of disabilities (Safani, Hanafi \& Nazri, 2014). According to a study, during their first year of teaching, the special education teachers are faced with multiple challenges, and they are twice and half times more tendency to leave their profession than general education teachers (Smith \& Ingersoll, 2004). In a study by Fantilli and McDougall (2009) that examined eighty-six novice teachers from two years teacher training program of Ontario graduates, pointed out that teaching for special needs students were ranked as the most challenging factor for any new teacher. Concerning this, Hastings and Brown (2002) declared that teachers of special education who had less efficacies indicated that the teachers are ineffectively deal with students' behavioral challenges, and also expected to be affected by undesirable responsive reactions. Service delivery issues, environmental climate, teacher preparation, student characteristics and student behavioral complexities may perhaps affect the perceptions and subsequent efficacy of teachers through their first year of service. 
INTERNATIONAL JOURNAL OF ACADEMIC RESEARCH IN BUSINESS AND SOCIAL SCIENCES Vol. 8, No. 7, July 2018, E-ISSN: 2222-6990 @ 2018 HRMARS

Students with special needs are quiet challenging to handle in a given situation, requires more time, and easily get frustrated as proclaimed by Lopes, Monteiro and Sil (2004). As such, a lot of teachers perceived that they are not ready to cater the needs of this type of students. Teachers may believe that some of the students might be a problem for them in the classroom and drops their efficiency level when teaching other students. Special education teachers also reported that they were often unprepared for the range of disabilities of students that they were required to teach, experienced unease situation when collaborating with their general education counterparts, and were overwhelmed with legal requirements, meeting preparations and data collection required, all of these are contributed to increase the level of difficulties. Teachers showed the senses of frustration and feeling guilty due to the period that is taken away from the most of the students to assist the needs of one student with special needs. Safani, Hanafi and Nazri (2014) declared that trainee's teacher started their profession with the sense of uncertainty and fear. There is also a higher probability that the pre-service teacher have a varied sentiment of curiosity, high expectation and anxiety. It is verified that efficacy related to the challenging student and profession that plays an important role in the determinations of special educators and if those difficulties are overcome, then, special education teachers can be more efficacious.

Being supported by resilience factor may, however, also be helpful to show efficacy. By activating affective, motivational, and behavioral mechanisms in challenging situations, resilience factor can promote efficacy beliefs. Efficacy therefore has sometimes been conceptualized as one component of resilience. Although several qualities are thought to be connected with resiliency, not all of these aspects have been empirically demonstrated to be valuable for the teachers' efficacy. These protective mechanisms may perhaps be either internal or external. This study extend the resilience factor not just focused on psychological aspects but also the external factor. The resilience, will allow the pre-service teachers abilities to continue teaching. Considerate the nurture of resilience, it is crucial to pursue and to enhance the efficacy of special educators.

Teacher training programs are further necessary to enroll and facilitate the teacher retention; mainly in high demands extents such as mathematics, science, and also special education. Meeting these challenges regularly leans on the training quality that candidate teachers received and their capability to apply and practice it. These consist of indicators of teaching programs, practices, and policies, and more subjective indicators such as teacher's efficacy or perceptions of control. The preparation of special education teachers has been given attention by the Ministry of Education, Malaysia. Since 1996 special education was given the equal concern as other areas in the progression of education in Malaysia. One of the moves in the Malaysia Education Blueprint 2013-2025 specifies that equal access to quality education of worldwide standard must be accessible to all (Ministry of Education, 2013). Hence, to certify that the objectives are not derailed, the Ministry of Education (MOE) has a central role in the qualified expansion of the teachers. Acting towards these standards of MOEs effort to prepare quality teachers is directed by the National Philosophy of Education and Philosophy of Teacher Education. In order to realize efficient teaching and learning in special education program, teachers have to be prepared and understand about the program (Asariah, 2009).

Additionally, the 21st century education systems have a clear demand for teachers that are adequately competent and motivated to embrace student with special educational needs in teaching (Lewis \& Sagree, 2013). As to improve the resilience, knowledge, attitude and confidence of the 
INTERNATIONAL JOURNAL OF ACADEMIC RESEARCH IN BUSINESS AND SOCIAL SCIENCES Vol. 8, No. 7, July 2018, E-ISSN: 2222-6990 @ 2018 HRMARS

teachers are necessary for the teachers to absorb, cultivate and practice during initial teacher preparation. It is also necessary for the teacher to provide opportunities for enduring efficiently professional learning through the teacher professions. The endurance of early career teachers is the recent concern in several countries inspecting features that uphold teachers as they transfer from the pre-service to the early profession phase will support in attending these concerns (Tait, 2008). Rather than reflect the form of retention of "physical continuation in the role", this emphasis on "quality retention" (Day \& Gu, 2007), where motivation and commitment are sustained as educators are able to encounter the challenges faced in their profession and lives and "thrive professionally".

\section{Methodology}

The design of this study is a quantitative correlational research. The questionnaires used in this study are of Special Education Career Resilience Scale (SECRS) by Sotomayor (2012), which measures four domains of the following themes; acceptance, support of self-awareness, conversion and connectedness and Teacher Self-efficacy Scale (TSES), adapted by Lee, Patterson and Vega (2011) that measures personal teaching efficacy and general teaching efficacy. This study descriptively measures the level of each domains as indicated by the pre-service teachers of special education in their response to the questionnaires. In order to identify the relationships between domains, correlation (correlation coefficient) is used to determine the existence of a relationship between domains, thus analyzing the aspects that predict teaching efficacy of special education pre-service teachers.

A total of 391 pre-service teachers of special education programs at three public universities in Malaysia are selected by purposive sampling in which the candidates have completed a two year teacher education program and have undergo practicum or school experience.

\section{Research Findings}

Level of Teaching Efficacy among Pre-Service Teacher of Special Education

Based on Table 1, the analysis of the construct of teaching efficacy shows a high level for personal teaching efficacy $(M=4.122, S D=.650)$ which refers to pre-teachers' feeling of confidence in regard to their teaching abilities, instructional research, enthusiasm to try a variety of resources and approaches, motivation to employ effective teaching methods and implementation of progressive and innovative approaches. However, the general teaching efficacy shows a moderate low level $(\mathrm{M}=$ $2.867, \mathrm{SD}=.520$ ). This indicates that the pre-service teachers have moderately low level of confidence on the task that is expected to be shifted when learners are subjected to vicarious learning experiences or social persuasion as well as the belief about the power of teaching to reach difficult children.

Table 1: The Overall Mean Score and Interpretation for Teacher Efficacy in Personal Teaching Efficacy and General Teaching Efficacy

\begin{tabular}{cccc}
\hline Construct & Mean & SD & Interpretation \\
\hline Teaching efficacy & & & High \\
Personal teaching efficacy & 4.122 & .650 & Moderate low \\
General teaching efficacy & 2.867 & .520 & . \\
\hline
\end{tabular}


INTERNATIONAL JOURNAL OF ACADEMIC RESEARCH IN BUSINESS AND SOCIAL SCIENCES Vol. 8, No. 7, July 2018, E-ISSN: 2222-6990 @ 2018 HRMARS

\section{Level of Resilience among Pre-Service Teacher of Special Education}

The external resilience factor is theme acceptance, while the psychological resilience factors are support for self-awareness, conversion and connectedness. Based on Table 2, the analysis of the resilience factors shows a high level of resilience in conversion $(M=4.151, S D=.7214)$. This presents that the pre-service teachers of special education in Malaysian public universities are respectably resilient in identifying and reaching their goals by means of internal motivation and tenacity. Secondly, there is high level of resilience in support for self-awareness $(M=4.082, S D=.6176)$, which refers to understanding of core values and interests that facilitate resilience in individuals, followed by moderate high level resilience in theme acceptance $(M=3.992$, $S D=.5620)$ that is the environment that supports resiliency through professional development. Finally, resilience in connectedness is found to be at moderately high level $(M=3.548, S D=.5309)$ which indicates moderate level of individual proactivity to attain goals or when encountering problem.

Overall, the mean for pre-service teachers' resilience is at moderately high level $(M=3.9985, S D=$ .562). This shows that pre-service teachers of Special Education in Malaysian public universities have satisfactory level of capacity to adapt and thrive despite experiencing adversity.

Table 2: The Overall Mean Score and Interpretation for Resilience in Theme Acceptance, Support for Self-Awareness, Conversion and Connectedness

\begin{tabular}{lccc}
\hline \multicolumn{1}{c}{ Construct } & Mean & SD & Interpretation \\
\hline Resilience & & & \\
Theme acceptance & 3.916 & .6520 & Moderate high \\
Support for self-awareness & 4.082 & .6176 & High \\
Conversion & 4.151 & .7214 & High \\
Connectedness & 3.548 & .5309 & Moderate high \\
\hline Overall & $\mathbf{3 . 9 9 8}$ & $\mathbf{. 5 6 2 0}$ & Moderate high \\
\hline
\end{tabular}

\section{Relationship between Resilience and Teaching Efficacy}

The Pearson correlation analysis explains the statistical relationship between resilience of pre-service teacher of special education and teaching efficacy. The efficacies in personal teaching efficacy and general teaching efficacy were examined in detailed with every component in resilience; theme acceptance, support for self-awareness, conversion and connectedness.

For personal teaching efficacy, there is a statistical significant relationship between each of the external and psychological resilience factor with personal teaching efficacy, with moderate positive relationship of resilience in support for self-awareness $[r=.669 * * ; p=0.000, p<.05]$, resilience in conversion $[r=.669 * * ; p=0.000, p<.05]$, and weak positive relationship with resilience in theme acceptance $\left[r=.250^{* *} ; p=0.000, p<.05\right]$ and resilience in connectedness $\left[r=.377^{* *} ; p=0.000, p<\right.$ .05]. This indicates that each component of resilience in theme acceptance, support for selfawareness, conversion and connectedness have a significant relationship with personal teaching efficacy among pre-service teachers of special education. 
INTERNATIONAL JOURNAL OF ACADEMIC RESEARCH IN BUSINESS AND SOCIAL SCIENCES Vol. 8, No. 7, July 2018, E-ISSN: 2222-6990 @ 2018 HRMARS

For general teaching efficacy, there is a statistical significant relationship between resilience with general teaching efficacy, whereby a positive relationship of resilience in theme acceptance $[r=$ $\left..171^{*} ; p=0.017, p<.05\right]$ which is are very weak positive (Evan, 1996). However, there is no relationship with other components of resilience; support for self-awareness $[r=.084 ; p=0.245, p>$ $.05]$, conversion $[r=.112 ; p=0.121, p>.05]$ and connectedness $[r=.045 ; p=0.537, p>.05]$. Our findings indicate that only resilience in theme acceptance has a significant relationship with general teaching efficacy of pre-service teachers of special education.

Overall, the external and psychological resilience factors have a positive relationship with personal teaching efficacy of pre-teachers of special education. The external resilience factors, on the other hand, demonstrated a significant relationship with general teaching efficacy of pre-service teachers of special education.

Table 3: Pearson Correlation Analysis for Components of Resilience and Teaching Efficacy

\begin{tabular}{lcccc}
\hline \multirow{2}{*}{ Correlations } & \multicolumn{3}{c}{ Teaching efficacy } \\
\cline { 2 - 5 } & \multicolumn{2}{c}{ PTE } & \multicolumn{2}{c}{ GTE } \\
\hline Resilience & Sig. & $r$-value & Sig. & $r$-value \\
Theme acceptance & & & & \\
Support of self-awareness & .000 & .250 & .017 & .171 \\
Conversion & .000 & .464 & .245 & .084 \\
Connectedness & .000 & .481 & .121 & .112 \\
\hline
\end{tabular}

\section{Predicting Teacher Efficacy Based on Aspects of Resilience}

The four construct of resilience were analyzed by regression analysis to determine the variables that predict teacher efficacy. Table 4 summarizes the results in regards to theme acceptance, support for self-awareness, conversion and connectedness.

Based on the regression analysis, the regression model that consists of theme acceptance, support for self-awareness, conversion and connectedness shows a significance of $35.0 \%$ for teaching efficacy among pre-service teachers of special education $[F(4,194)=25.396, p=0.000, p<.05]$. However, only resilience in conversion $(b=-.256, t=2.002, p<.05)$ is the significant predictor for teaching efficacy.

The regression equation for the analysis is:

$\mathrm{Y}^{\wedge}=.256 \mathrm{x}_{1}+1.781$ 
INTERNATIONAL JOURNAL OF ACADEMIC RESEARCH IN BUSINESS AND SOCIAL SCIENCES Vol. 8, No. 7, July 2018, E-ISSN: 2222-6990 @ 2018 HRMARS

Table 4: Regressions Analysis of Aspects of Resilience

\begin{tabular}{lccccc}
\hline & $\boldsymbol{B}$ & Std Error & Beta & t & Sig. \\
\hline Resilience (Constant) & 1.781 & .247 & & 7.223 & .000 \\
1. Theme acceptance & .027 & .041 & .049 & .643 & .521 \\
2. Support of self-awareness & .152 & .078 & .264 & .1 .947 & .053 \\
3. Conversion & .127 & .063 & .256 & 2.022 & .045 \\
4. Connectedness & .069 & .047 & .102 & 1.475 & .142 \\
\hline
\end{tabular}

\section{Discussion}

The findings of this study demonstrate that the level of personal teaching efficacy among pre-service teacher of special education is high. This result also indicates that the pre-service teachers mostly perceive high personal teaching efficacy (PTE) which represents a teacher's belief that possessing the skills and abilities to facilitate student learning is the teacher's overall sense of own teaching effectiveness. It also clarifies that the pre-service teachers have high instructional experimentation, including willingness to try a variety of materials and approaches, the desire to find better ways of teaching, and implementation of progressive and innovative methods (Abuhmaid, 2011). On the contrary, the general teaching efficacy of pre-service teacher of special education in Malaysia public universities shows a moderately low level in which the belief that teaching can affect pupils positively, even in light of external factors or conditions such as low motivation or poor home environment. It also explains that the teachers are moderately low of "appears to reflect a general belief about the power of teaching to reach difficult children" (Hoy \& Spero, 2005).

These findings are in line with Gavora (2010) who perceived that personal teaching efficacy item mean scores in all countries are at higher level than general teaching efficacy, except of Turkey with a very slight mean value different of .12. Pre-service teacher with increased personal teaching efficacy were regarded more confidently on teaching presenting performance, classroom organization, and questioning actions by their supervising teacher on their practicum evaluation (Sivri \& Balci, 2015). Not surprisingly at this point, the pre-service teacher felt that they had the least power. As stated by Hoy (2000), general teaching efficacy appears to upsurge through university coursework, then decrease during student teaching indicating that the confidence of early teachers may slightly decline once faced with the realities and complexities of the teaching task.

Gavora (2010) declared that a teacher may have high personal teaching efficacy but may believe that external influences affect pupils' learning, or vice versa. Thus, a teacher may be convinced of his or her own ability to teach but doubtful about pupils' ability to learn successively or may believe that pupils' ability to learn is irrespective of teacher own inability to teach. Nevertheless, Gibson and Dembo (1984) found that teachers who scored high on both dimensions were more likely to persist if a student failed a learning task initially.

Consequently, this study focuses on the relationship of personal teaching efficacy and general teaching efficacy with external and psychological resilience factors. It shows that the higher the resilience level, the higher the teaching efficacy of the pre-service teachers of special education. Research has shown that teacher efficacy is related to student achievement and that efficacious 
INTERNATIONAL JOURNAL OF ACADEMIC RESEARCH IN BUSINESS AND SOCIAL SCIENCES Vol. 8, No. 7, July 2018, E-ISSN: 2222-6990 @ 2018 HRMARS

teachers have a stronger sense of resiliency (Goddard, Hoy \& Hoy, 2000; Hoy \& Spero, 2005; Skaalvik \& Skaalvik, 2010).

For personal teaching efficacy, the results showed that there is a statistical significant relationship with moderate positive relationship of support for self-awareness and conversion, whereas a weak positive relationship for theme acceptance and connectedness. Still, this indicates that each component of resilience in theme acceptance, support for self-awareness, conversion and connectedness has a significant relationship with personal teaching efficacy among pre-service teachers of special education. It simplifies the explanation by Cantrell, Moore and Young (2003) that teachers with a personal teaching efficacy have confidence that they have adequate training or experience to develop strategies for overcoming obstacles to student learning. Such teachers will expend great effort to reach goals, will persist longer in the face of adversity, and rebound from temporary setbacks to a greater degree.

For general teaching efficacy, the analysis showed that there is a statistical significant relationship between resilience in theme acceptance, which also refers to the external resilience factors. It also indicates that only theme acceptance has a significant relationship with general teaching efficacy of pre-service teachers of special education. These findings appear to refute findings of previous researchers by Lee, Patterson and Vega (2011) that personal teaching efficacy is closely related to the levels of support from school (Urton, Wilbert \& Hennemann, 2014). In this study, the general teaching efficacy also appears to be linked with the levels of support from school. Accordingly, it was based on social encouragement which may promote to efficacious performances to the point that a persuasive support directs an individual challenge to new strategies or to try effectively to succeed (Tsai, 2011). School systems as well as role of principals, experienced teacher and other colleagues should display supportive strong leadership, open, and well-organized and encouraging feedback given. "Strong caring leadership" is an important source of personal support (Howard \& Johnson, 2004). Pre-service teachers should be assisted by ensuring their attainments and involvements to the school are recognized (Cornu \& Ewing, 2007). Visible and continuous sensible support in leadership and performance is necessary (Goddard \& Foster, 2001; deMatthews, 2015; Hoopey and McLeskey, 2013; Lindqvist and Nilholm, 2014; Nichols and Sheffield, 2014).

Another key finding is that resilient teachers possess a sense of efficacy, more confident and competent. It is significant for the teachers to have strong and enduring resilience to be effective and better sense of efficacy (Beltman, Mansfield \& Price, 2011). "Teachers' self-efficacy is a little view with significant impact" (Tschannen-Moran \& Woolfolk Hoy, 2007), through "a reflective relation by resilience and persistence" (Kitching, Morgan \& O'Leary, 2009). Efficacy values seem to be most simply impacted in the early years of teaching practice and slightly resistant to shift when established" (Tait, 2008).

On an optimistic remark, somewhat of just considered as internal or psychological attributes (Gu \& Day, 2007), the qualities of resilient teachers can be cultured (Howard \& Johnson, 2004). Castro, Kelly and Shih (2010) considered resilience as a process of adaptation instead of just personal attributes. Within the process, persons are viewed as dynamic representatives that utilize strategies to face challenges in their situation. Sufficient articles discussed the references for pre-service teacher 
INTERNATIONAL JOURNAL OF ACADEMIC RESEARCH IN BUSINESS AND SOCIAL SCIENCES

Vol. 8, No. 7, July 2018, E-ISSN: 2222-6990 @ 2018 HRMARS

education, for fostering several individual attributes and skills, creating a climate of resilience at university and continuing connected with graduates at the beginning phase of teaching.

\section{Conclusion}

This study shows a high level of confidence in personal teaching efficacy, but moderately low level of confidence in general teaching efficacy. These findings align with conclusion drawn from previous studies that also identify the level of teaching efficacy among pre-teachers of special needs education. Furthermore, the level of resilience among the pre-teachers is found to be moderately high. Our study also finds that resilience factors have a positive and significant relationship with teaching efficacy, in which conversion being an essential predictor to teaching efficacy. In short, this study suggests the importance of resilience factors, both external and psychological factors, to enhance the teaching performance of pre-teachers. The commitment and resilience of pre-teachers is very important to achieve the objectives and the goal of a program. Pre-service teachers, as well as new teachers, should be optimistic and competently belief on special education to be more positive and practice more professionally. In other words, this study implicates pre-service teachers of special education to perceive both psychological and external resilience factors to enhance their teaching efficacy, professionally.

\section{References}

Abuhmaid, A. (2011). ICT training courses for teacher professional development in Jordan, Turkish Online Journal of Educational Technology - TOJET, 10 (4): 195-210.

Asariah Mior Shaharuddin. (2009). The next generation of teachers: The Malaysian perspective. Paper presented at 13th UNESCO-APEID International Conference on Education and World BankKERIS High Level Seminar on ICT in Education. Hangzhou, People's Republic of China. 15-17 November.

Beltman, S., Mansfield, C., \& Price. (2011). Thriving not just surviving: A review of research on teacher resilience. Educational Research Review, 6, 185-207.

Betoret, F. D. (2009). Stressors, self-efficacy, coping resources, and burnout among secondary school teachers in Spain. Educational Psychology, 26, 519 -539.

Bong, M. (2008). Effects of parent-child relationships and classroom goal structures on motivation, help-seeking avoidance, and cheating. Journal of Experimental Education, 76 (2), 191-217.

Cantrell, P., Moore A, \& Young S. (2003) Factors affecting science teaching efficacy of pre-service elementary teachers. Journal of Science Teacher Education, 14(3), 177-92

Castro, A., J., Kelly, J., \& Shih, M. (2010). Resilience strategies for new teachers in high-needs areas. Teaching and Teacher Education, 26, 622 - 629.

Cornu, R. L. \& Ewing, R. (2007). Re-conceptualizing professional experiences in pre-service teacher education...reconstructing the past to embrace the future. Science Direct, 24, 1799 - 1812

Gu, Q., \& Day, C. (2007). Variations in the conditions for teachers' professional learning and development: Sustaining commitment and effectiveness over a career. Oxford Review of Education, 33 (4), 423-443.

Dibapile, W. T. S. (2012). A Review of Literature On Teacher Efficacy And Classroom Management. Journal of College Teaching and Learning, 9 (2), 79-92.

D’Elisa, T. M. (2015). Student Motivation: Teacher Perceptions, Beliefs and Practices. PCOM Psychology Dissertations. Paper 338. 
INTERNATIONAL JOURNAL OF ACADEMIC RESEARCH IN BUSINESS AND SOCIAL SCIENCES

Vol. 8, No. 7, July 2018, E-ISSN: 2222-6990 @ 2018 HRMARS

Dematthews, D. (2015). Making Sense of Social Justice Leadership: A case study of a principal's experiences to create a more inclusive school. Leadership and Policy in Schools, 14(2), 139166.

Eichinger, J. (2000). Job stress and satisfaction among special education teachers: Effects of gender and social role orientation. International Journal of Disability, Development and Education, 47(4), 397-412.

Eren, A. (2009). Examining the teacher efficacy and achievement goals as predictors of Turkish student teachers' conceptions about teaching and learning. Australian Journal of Teacher Education, 34, 69-87.

Fantilli, R.D., \& McDougall, D. E. (2009) A study of novice teacher: challenges and supports in the first years. Teaching and Teacher Education, 25, 814-825.

Gavora, P. (2010). Pre-service teacher self-efficacy: theoretical and research considerations. The New Educational Review, 21 (2), 17-30.

Gibbs, S., \& Powell, B. (2012). Teacher efficacy and pupil behavior: The structure of teachers' individual and collective beliefs and their relationship with numbers of pupils excluded from school. British Journal of Educational Psychology, 82(4), 564-584.

Gibson, S., \& Dembo, M. (1984). Teacher efficacy: A construct validation. Journal of Educational Psychology, 76, 569-582.

Goddard, J., \& Foster, R. (2001). The Experiences of neophyte teachers: A critical constructivist assessment. Teaching and Teacher Education, 17, 349-365.

Goddard, R. G., Hoy, W. K., \& Hoy, W. A. (2000). Collective teacher efficacy: Its meaning, measure, and impact on student achievement. American Educational Research Journal, 37, 479-508.

Hastings R. P. \& Brown T. (2002). Behavioral knowledge, causal beliefs and self-efficacy as predictors of special educators' emotional reactions to challenging behaviors. Journal of Intellectual Disability Research 46, 144-150.

Hightower, A. M., Delgado, R. C., Lloyd, S. C., Wittenstein, R., Sellers, K. \& Swanson, C. B. (2011). Improving Student Learning By Supporting Quality Teaching: Key Issues, Effective Strategies. MD: Bethesda.

Hoopey, D. \& McLeskey, J. (2013). A case study of principal leadership in an effective inclusive school. The Journal of Special Education, 46(4), 245-256.

Howard, S., \& Johnson, B. (2004). Resilient teachers: Resisting stress and burnout. Social Psychology of Education, 7(4), 399-420.

Hoy,W. A., \& Spero, R. (2005). Changes in teacher efficacy during the early years of teaching: A comparison of four measures. Teaching and Teacher Education, 21, 343-356.

Kitching, K., Morgan, M., \& O'Leary, M. (2009). It's the little things: Exploring the importance of commonplace events for early-career teachers' motivation. Teachers and Teaching: Theory and Practice, 15(1), 43-58.

Klassen, R. M. (2007). Using predictions to learn about the self-efficacy of early adolescents with and without learning disabilities. Contemporary Educational Psychology, 32(2), 173-187.

Lazaras, L. (2006). Occupational stress, negative affectivity and physical health in special and general education teachers in Greece. British Journal of Special Education, 33(4), 204-209.

Lee ,Y., Patterson, P. P. \& Vega L. A., (2011). Perils to self-efficacy perceptions and teacherpreparation quality among special education intern teachers. Teacher Education Quarterly, $38(2), 61-76$. 
INTERNATIONAL JOURNAL OF ACADEMIC RESEARCH IN BUSINESS AND SOCIAL SCIENCES

Vol. 8, No. 7, July 2018, E-ISSN: 2222-6990 @ 2018 HRMARS

Lewis, I. \& Sagree, S. (2013). Teachers for all: Inclusive teaching for children with disabilities. International Disability and Development Consortium Report. Hollingsworth, Cheshire: Enabling Education Network.

Lindqvist, G. \& Nilholm, C. (2014). Promoting inclusion? 'Inclusive' and 'effective head teachers' descriptions of their work. European Journal of Special Needs Education, 29(1), 74-90.

Lopes, J. A., Monteiro, I., \& Sil, V. (2004). Teachers' perceptions about teaching problem students in regular classrooms. Education and Treatment of Children, 27(4), 394-419.

Martin, A. (2006). The relationship between teachers' perceptions of student motivation and engagement and teachers' enjoyment of and confidence in teaching. Asia-Pacific Journal of Teacher Education, 34(1), 73-93.

Ministry of Education (2013). Malaysia Education Blueprint 2013-2025 (Preschool to Post-Secondary Education).

Nichols, S. C. \& Sheffield, A. N. (2014). Is there an elephant in the room? Considerations that administrators tend to forget when facilitating inclusive practices among general and special education teachers. National Forum of Applied Educational Research Journal, 27(2), 31-44.

Ravikumar, M. (2013). Pre-service elementary teachers' self-efficacy beliefs about science using critical incident technique: a case study approach. Electronic Theses and Dissertations, 2680, $1-181$.

Safani Bari, Mohd Hanafi Mohd Yasin, Mohd Nazri Hamzah (2014). The Readiness of Special Education Trainees to Teach in Inclusive Program. International Education Studies, 7(13), 206-211

Sivri, H. \& Balci, E. (2015). Pre-service Teachers' Classroom Management Self-efficacy Beliefs. International Online Journal of Educational Sciences, 7 (4), 37 - 50

Skaalvik, E.M., \& Skaalvik, S. (2010). Teacher self-efficacy and teacher burnout. Teaching and Teacher Education, 26, 1059-1069.

Smith, T., \& Ingersoll, R. (2004). What are the effects of induction and mentoring on beginning teacher turnover? American Educational Research Journal, 41, 681-684.

Somech, A. \& Drach-Zahavy, A. (2000). Understanding extra-role behavior in schools: The relationships between job satisfaction, sense of efficacy, and teachers' extra-role behavior. Teaching and Teacher Education, 16, 649-659.

Sotomayor (2012). Career Resilience And Continuing Special Education Teachers: The Development And Evaluation Of The Special Education Career Resilience Scale. Digital Repository at the University of Maryland, (301), 314-1328.

Spector, J. E. (1990, April). Efficacy for teaching in pre-service teachers. Paper presented at the Annual Meeting of the American Educational Research Association, Boston.

Strong, M., Gargani, J., \& Hacifazlioglu, O. (2011). Do we know a successful teacher when we see one? Experiments in the identification of effective teachers. Journal of Teacher Education, 62(4), 367-382.

Tait, M. (2008). Resilience as a contributor to novice teacher success, commitment, and retention. Teacher Education Quarterly, 35(4), 57-75.

Tsai, Y. (2011). Relationship between Organizational Culture, Leadership Behavior and Job Satisfaction. BMC Health Serv Res. 11, 98.

Tschannen-Moran, M. \& Hoy, W. A. (2001). Teacher efficacy: capturing the elusive construct. Teaching and Teacher Education, 17, 783 - 805.

Tschannen-Moran, M. \& Hoy, W. A. (2007). The differential enticident of self-efficacy belief of novice and experienced teachers. Teaching and Teacher Education, 23, $944-956$. 
INTERNATIONAL JOURNAL OF ACADEMIC RESEARCH IN BUSINESS AND SOCIAL SCIENCES

Vol. 8, No. 7, July 2018, E-ISSN: 2222-6990 @ 2018 HRMARS

Tschannen-Moran, M., \& Johnson, D. (2011). Exploring literacy teachers' selfefficacy beliefs: Potential sources at play. Teaching and Teacher Education, 27 (4) 751-761.

Urton, K., Wilbert, J. \& Hennemann, T. (2014). Attitudes towards inclusion and self-efficacy of principals and teachers. Learning Disabilities: A Contemporary Journal, 12(2), 151-168.

Wright, H. D. (2013). The relation between high school teacher sense of teaching efficacy and selfreported attitudes toward the inclusive classroom settings. Doctoral Dissertations and Projects, 668. 